This study of commercial diplomacy investigates the responses of British industry and government to foreign competition, sectoral depression and decline. It examines the attitude of the British iron and steel industry towards the cartel of the continental steel industries and the attempt of the Lancashire cotton industry in 19.32-34 to reach a market-sharing agreement with Japan.

The author shows that after the 'black decade' of the I 920 s the British steel industry, aided by tariff protection and an expanding domestic market, achieved in the I930s a position of primacy in the British political and industrial system. With the support of the government and the Import Duties Advisory Committee - whose central role is brought out clearly in the book - the industry concluded an agreement in 19.35 with the continental steel export cartel which guaranteed it control of the domestic market. No such official patronage was forthcoming for the cotton industry. The government refused Lancashire's vehement demands for protection against Japanese competition. Conscious of Britain's military weakness in the Far East and anxious to appease Japan. the government pressured the industry into cartel negotiations, which were to end in failure.

Using a wide range of primary sources, the author provides an analysis of the relationship between government and industry in Britain and of the role of the state in British industrial politics and in the management of industrial decline. He shows that the outcome of international negotiations in the steel and cotton industries was not determined by economic factors alone, but was influenced decisively by diplomatic and political considerations. 

Business, politics and international relations 
This book is published as part of the joint publishing agreement established in 1977 between the Fondation de la Maison des Sciences de l'Homme and the Press Syndicate of the University of Cambridge. Titles published under this arrangement may appear in any European language or, in the case of volumes of collected essays, in several languages.

New books will appear either as individual titles or in one of the series which the Maison des Sciences de l'Homme and the Cambridge University Press have jointly agreed to publish. All books published jointly by the Maison des Sciences de l'Homme and the Cambridge University Press will be distributed by the Press throughout the world.

Cet ouvrage est publié dans le cadre de l'accord de co-éditions passé en 1977 entre la Fondation de la Maison des Sciences de l'Homme et le Press Syndicate de l'Université de Cambridge. Toutes les langues européennes sont admises pour les titres couverts par cet accord. et les ouvrages collectils peuvent paraître en plusieurs langues.

Les ouvrages paraissent soit isolément, soit dans l'une des séries que la Maison des Sciences de l'Homme et Cambridge University Press ont convenu de publier ensemble. La distribution dans le monde entier des titres ainsi publiés conjointement par des deux ètablissements est assuré par Cambridge University Press. 


\section{BUSINESS, POLITICS AND INTERNATIONAL RELATIONS}

STEEL, COTTON AND INTERNATIONAL

CARTELS IN BRITISH POLITICS, I 924-I 939

\section{CLEMENS WURM}

Professor of West European History. Humboldt University of Berlin

TRANSLATED BY PATRICK SALMON 


\section{CAMBRIDGE UNIVERSITY PRESS}

Cambridge, New York, Melbourne, Madrid, Cape Town, Singapore, São Paulo, Delhi

Cambridge University Press

The Edinburgh Building, Cambridge CB2 8RU, UK

With Editions de la Maison des Sciences de l'Homme 54 Boulevard Raspail, 75270 Paris Cedex 06, France

Published in the United States of America by Cambridge University Press, New York

www.cambridge.org

Information on this title: $w w w . c a m b r i d g e . o r g / 9780521108768$

Originally published in German as Industrielle Interessenpolitik und Staat. Internationale Kartelle in der britischen Aussen- und Wirtschafispolitik Während der Zwischenkriegszeit by Walter de Gruyter \& Co. 1988

and (C) Walter de Gruyter \& Co., Berlin and New York

First published in English by Editions de la Maison des Sciences de l'Homme and Cambridge University Press 1993 as Business, politics and international relations: Steel, cotton and international cartels in British politics, 1924-1939 English translation $\mathbb{C}$ Maison des Sciences de l'Homme and Cambridge University Press 1993

This publication is in copyright. Subject to statutory exception and to the provisions of relevant collective licensing agreements, no reproduction of any part may take place without the written permission of the copyright holder.

This digitally printed version 2009

A catalogue record for this publication is available from the British Library

ISBN 978-0-521-40520-1 hardback

ISBN 978-0-521-10876-8 paperback 
To Cornelius, Katharina and Annette 
